THURSDAY, NOVEMBER 27, I9I9.

\section{THE ROYAL COMMISSION ON THE UNIVERSITIES OF OXFORD AND CAMBRIDGE.}

SEVERAL months ago, Mr. H. A. L. Fisher, President of the Board of Education, made the important announcement that the Government had decided to appoint Commissions to inquire into the position of the Universities of Oxford and Cambridge. At both Universities the existing resources have proved inadequate to meet the increased cost of maintenance of the various departments, and the authorities of each independently applied to the Government for financial aid. It was understood that in due course comprehensive inquiries into the whole resources of the Universities and their colleges, and the use made of them, would be instituted; and preliminary grants of $30,000 l$. to each University were accepted on this condition. With reconstruction in the air and Government inquiries in the fashion, it is not surprising, therefore, that a Royal Commission (under the chairmanship of $\mathrm{Mr}$. Asquith), with separate Committees for Oxford and Cambridge, and a further Committee dealing with estate management, has now been appointed to inquire into the financial resources of the two Universities and of the colleges, into the administration and application of these resources, into the government of the Universities, and into the relation of the colleges to the Universities and to each other.

It is more than forty years since the last Royal Commission on the Universities of Oxford and Cambridge was appointed, and the advisability of a new Commission has frequently been suggested in recent years. The question was debated in the House of Lords in I907, but it was believed at the time that it would be better for the Universities to institute reforms from within; and at Oxford the Chancellor, Lord Curzon, made an extensive inquiry into the possibility of such reforms, following it up by an open "letter" addressed to the University, containing a number of valuable suggestions. Some of these have since been acted upon, but others, such as the abolition of compulsory Greek in the entrance examination, have temporarily succumbed to the conservatism of certain membet's of the University, more especially the ron-resident members of Convocation. Still other questions, such as that relating to degrees for women, have been postponed owing to the war, but they are likely to come up for consideration in a very short time. No. 26 I 3 , VOL. IO4]
Hence there would not have been any very cogent grounds for the immediate appointment of a fresh Commission, had it not been for finance. At Oxford, whilst the income of the University has fallen, its expenses have greatly increased. Science in particular, owing to the increase in the number of its students and to the range of their studies, has been forced to make special demands for further laboratory accommodation and for increased grants for teaching purposes.

Considering the special needs of science, the composition of the Oxford Committee is not altogether satisfactory. Of the nine members of the Committee, only two are men of science, whilst in the Cambridge Committee science has been assigned twice as great a representation. However, there can be no question of the suitability of the scientific representatives themselves. One of them, Sir Henry Miers, when professor of mineralogy at Oxford, was of invaluable assistance, by his moderation and persuasiveness, in bringing the just claims of sciance before the resident members of the University. Prof. W. H. Bragg will bring to the inquiry the freshness and width of outlook of one who has had experience of research and professorial teaching in two hemispheres. Miss Penrose, the principal of Somerville College, is a worthy exponent of the claims of women, while Labour is presumably represented by Mr. A. Mansbridge.

The Cambridge Committee is one to which, at any rate as individuals, and from the point of view of the University itself, little exception can be taken. It contains one woman (Miss Clough), one representative of Labour (Mr. Arthur Henderson), six (or, including Miss Clough, seven) members of the University, and four distinguished fellows of the Royal Society, namely, Sir W. Morley Fletcher, Sir Horace Darwin, Dr. H. K. Anderson, and Prof. A. Schuster. It is, however, a pity that the younger generation should be so inadequately represented. The Committee has an average age of about sixty years, and although there are many really distinguished members of the University between the ages of twenty-eight and forty-three, and it is these men who will have mainly to bear the brunt of the next twenty years, there is nobody on the Committee to emphasise their point of view. The absence also of an expert in finance, industry, or economics is noteworthy, and-one would imagine--will make the task of the Committee more difficult.

Apart from these objections, however, it is clear that Cambridge has nothing to fear, and may have much to gain, from its Committee's activities. The four scientific members are known as men of sound judgment, wide knowledge, and an enthusi- 
asm for scientific progress, while they have been as much concerned with the importance of science to the well-being and prosperity of the community as with its value in education and in the improvement of human knowledge. All of them are men who personally have done valuable original research, and shown the capacity for affairs and the sound judgment necessary in these days of organised scientific work.

The terms of reference of the Commission relate, not only to questions of finance, but also to the government of the Universities and the relations of the colleges to the Universities and to each other; hence the inquiry is likely to be an extensive one. In the course of the inquiries to be made, many anomalies will doubtless be revealed. Our educational structure is curiously unbalanced. It has grown up cathedrallike, and bears witness to the loving, if sometimes misguided, benefactions of many generations. We trust that the Commissioners, while retaining all that is good-and there is much that is worthy of preservation-will ensure a more economical and equitable distribution of the fruits of past benefactions for the encouragement of religion, learning, education, and research.

In particular, we would direct attention to the need for greater facilities for research, not only in pure science, but also in modern philosophy. It is almost incredible that Oxford, the home of classical learning, cannot boast of a single exponent of modern philosophy who might be expected to explore the regions of thought revealed by recent scientific research on space and time. The discontinuities of modern physics should surely not appeal in vain to the heirs of the wisdom of the Greek philosophers.

Further, the hard-worked science tutor should be afforded time and facilities for research. A critical study by the Commissioners of the distribution of tutors in the various subjects and of the relative number of pupils allotted to each tutor would form an instructive lesson on our educational methods. Some relief could be given to science tutors if it were made compulsory for candidates for degrees in science to obtain exemption from preliminary physics and chemistry before admission to the University. This would also relieve the already overburdened laboratories.

Other questions relating to natural science with which the Commission must deal are: (a) The urgent need for further buildings and equipment, and for increased staff, if the present rush of students is to be met, and if research is to be maintained; $(b)$ the sufficient remuneration of the NO. 26I 3 , VOL. IO4] teaching and research staffs, and the recognition of the fact that the research worker is no less entitled to payment for his labours than the business man, the teacher, or the labourer; $(c)$ the better support of natural science by the colleges (in proportion to its importance, natural science is inadequately assisted by many colleges in the matter of scholarships, fellowships, and lectureships); (d) the provision of pensions for professors and other officials, and the introduction of a definite age for retirement. This last matter is particularly important in natural science, where the professors have administrative and organising duties, as well as those of lecturing and directing research, and there is no reason why a university should be an exception to the general rule in any large undertaking, national or private, that an executive appointment should be subject to an age limit.

The Committee on Estate Management will have to consider the more efficient administration of college property, and may recommend the adoption universally of the system already agreed to by three important colleges at Cambridge of employing a common estate office connected with the School of Agriculture. The present system of awarding scholarships, the subject of women's degrees, the finances of the women's colleges, and the cost of living of the average undergraduate are among the more controversial matters to be decided. Whatever may be the course of their deliberations, however, it is clear that Cambridge will not be encouraged, as it might have been under another type of Commission, to cease its national function as a home of "religion, learning, and research," and to become a place merely of technical instruction. Whatever faults the Commission may have will lie, not in a lack of sympathy for education and research in the best sense, but in a rather conservative outlook and an inability to understand the urgency of really radical changes, in an insufficient appreciation of the needs and demands of the great labouring classes of the country, and in lack of understanding of the point of view of the younger generation.

PRINCIPLES OF RADIO-COMMUNICATION. The Principles underlying Radio-communication.

Radio Pamphlet No. 40. December ro, 1918.

Signal Corps, U.S. Army. Pp. 355. (Washington: Government Printing Office, I9I9.) Price 55 cents.

THIS book has been prepared by the Bureau of Standards, Washington, under the direction of the Chief Signal Officer of the Training 